\title{
Post-Divorce Parental Conflict and Adolescents' Delinquency in Divorced Families
}

\author{
Nooshin Sabour Esmaeili (Correspondence Author) \\ Faculty of Human Ecology, University Putra Malaysia \\ 43400 UPM Serdang, Selangor, Malaysia
}

Tel: 60-1-7326-9351 E-mail: noshin_sabori_e@yahoo.com

Siti Nor Yaacob

Faculty of Human Ecology, University Putra Malaysia

43400, UPM Serdang, Selangor, Malaysia

Tel: 60-1-2284-1844 E-mail: siti nor@putra.upm.edu.my

Received: January 27, 2011 Accepted: March 11, 2011 doi:10.5539/ach.v3n2p

\begin{abstract}
This study reviews several empirical researches which highlight the effect of post-divorce parental conflict as one of the most important factors on adolescents' delinquency in divorced families. Research consistently shows that parental conflict affects parental relationship and this poor parental quality may transfer into poor parent-child relationship that may negatively influence adolescent functions and behaviors. Research showed that adolescents who are exposed to post-divorce parental conflict are at increased risk for high level of delinquency. Positive associations between parental conflict and adolescent delinquency have been accounted for by parental rejection or withdrawal, parental hostility toward adolescents, lack of parental warmth, and corporal punishment and parent-adolescent conflict.
\end{abstract}

Keywords: Adolescent, Post-divorce parental conflict, Delinquency

\section{Introduction}

In recent decades family structures are undergoing changes due to the high rate of divorce (Heck \& Walsh, 2000).Divorce has become significantly more common and it is a life crisis for almost all families who experience it. The high number of divorced families over the past decade has raised concern regarding the effect of divorce on children and adolescents (Amato, 2000; Kelly, 2003; Hetherington, 2003; VanderValk et al., 2004). Researchers have found that parental divorce place children and adolescents at greater risk of adjustment problems (Amato \& Keith, 1991; Amato, 2000; Kelly, 2000; Hetherington, 2003; Kelly \& Emery, 2003: Dimitrieva et al., 2004: Santrock, 2007) especially externalizing problems such as aggression, antisocial behavior problems and delinquency, and internalizing problems such as depression, anxiety and self-esteem and low level of academic performance (Hetherington et al., 1993; Amato, 2001; Malone et al., 2004; Demuth \& Brown, 2004; Lansford et al., 2006).

Studies in recent decade has focused on understanding the processes by which parental divorce affects children and identifying a variety of protective and vulnerability factors which moderate or mediate these effect. It is believed that the combination of factors such as loss of contact with non-custodial parent, adjustment of custodial parent, post-divorced parental conflict, parental psychological distress, the quality of parent-adolescent relationship, parental economic hardship, and the quality of parenting mediate the effect of divorce on children and adolescent behavior 
problems (Amato, 1993; Hetherington et al., 1998; Amato, 2000; Kelly, 2000; Grych, \& Fincham, 2001; Kelly, 2002: Kelly, 2003; Hetherington, 2003; Kelly, 2007, Ingeram et al., 2007).

Children's age at the time of parental divorce, children's gender, and length of parental divorce, parental education and employment status, social and emotional support from family and friends, and coping skills may also moderate the link between parental divorce and adolescent adjustment. Some researchers have found no significant effect of family structure on children and adolescents outcome; rather, indicators such as continuing parental conflict following divorce are more critical.

Post-divorce parental conflict is an important predictor for the development of behavioral, social and emotional problems in children and adolescents (Amato \& Keith, 1991; Emery, 1999; Grych, \& Fincham, 2001; Arnett, 2004; Davies \& Lindsay, 2004; Gerard et al., 2006; Houseknecht \& Hongo, 2006; Cui et al., 2007; Kim et al., 2008). More generally, children and adolescents whose parents have high level of conflict following divorce are less well adjusted to their parental divorce (Amato, 2000). Exposure to post-divorce parental conflict can be stressful for adolescents and can negatively affect their health and well-being. These relations have been found for both girls and boys during their childhood and adolescents.

The main purpose of this article is to analyze previous studies on the relationship between postdivorce parental conflict and adolescents' delinquency. Children from divorce families were noted to be more delinquent than those from intact families (Amato \& Keith, 1991; Kelly, 2000; Hetherington, 2003).

\section{Post-divorce parental Conflict}

Post-divorce parental conflict is characterized by parents' inability to communicate politely, parental battles, and hostility (Neff \& Cooper, 2004). It is often assumed that parents in highconflict marriages continue their conflict after divorce and separation (Hetherington, 2003). Studies have shown that 8 to 15 percent of parents continue high conflict, 2-3 years after divorce (Kelly, 2000, Kelly, 2003). There is considerable evidence that most children experience high conflict, verbal and physical violence during their parental divorce (Kelly, 2000; Booth \& Amato, 2001; Kelly \& Emery, 2003). High conflict between parents following divorce can be traumatic, destroying, and extremely stressful for children and adolescents and it is also the most significant factor for children and adolescents' behavior problems (Amato \& Keith, 1991; Emery, 1999; Amato, 2000; Arnett, 2004; Sandler et al., 2008).

Emery (1999) in his book "Marriage, divorce, and children's adjustment", noted that parental conflict following parental divorce is significantly related to externalizing behavior problems in children and adolescents. Amato (2000) asserted that family conflict before and after divorce may cause more harm to children and adolescents. Amato also reported that parents' conflict increases the risks of children's behavioral problems. It has been found that post-divorce parental conflict is more important in influencing the functioning of adolescents than parental divorce.

Sandler et al. (2008) studied the relationship between children's mental health problems and the level of conflict between the parents by using a sample of 182 divorcing families. Results indicated that father warmth and mother warmth were both independently related to lower child-externalizing behavior problems. However, the relations between mother and child warmth and child-internalizing problems were different as a function of inter-parental conflict and level of warmth with the other parent.

Children and adolescents are not the only persons who suffer the consequences of post-divorce parental conflict. Conflict between parents affects parents relationship and this may reduce parent-child relationship, and their ability to recognize and respond to children's emotional needs that may negatively influence child and adolescent functions and behaviors (Kelly, 2000; Amato, 2003; Kelly \& Emery, 2003; Guttman \& Rosenberg, 2003; Grych, 2005; Bradford et al., 2007; Platt et al., 2008). Divorced parents with high level of conflict may experience greater 
difficulty in being consistent toward their children's demands, patient with their children and in finding enough time to play with their children (Pruett et al., 2003).

Parental conflict also may decrease parental warmth and parental support that reduced control of children behavior, parental monitoring and parent-child relationship, but increased verbal hostility, physical and harsh punishment through the children (Turner \& Kopiec, 2006; Bradford et al., 2007). High conflict is more destructive when parents place their children in the middle of their conflict. When parents express their anger and carry their hostile messages, express verbal or physical aggression to each other in presence of the children, their children and adolescents are more likely to be depressed, anxious, and poorly adjusted compared to children and adolescents whose high-conflict parents leave their children out of their anger (Kelly \& Emery, 2003; Kelly, 2007).

\section{Post-divorce parental conflict and delinquency}

Many researchers have found that for most children and adolescents divorce marks the beginning of problems. It is important to note that the responses of children and adolescents to divorce is mediated by many factors, such as exposure to continuing post-divorce parental conflict (Amato \& Keith, 1991). The level and intensity of conflict between parents during marriage is indicative of post-divorce conflict, hostility and distress.

Post-divorce parental conflict is a consistent predictor of behavior problems among adolescents. Growing body of literature has found the association between parental conflict and adolescent behavior problems. These researches emphasized that when children and adolescents are exposed to frequent, intense, and unresolved parental conflict, they exhibit more externalizing symptoms such as delinquency (Kelly, 2000; Schickedanz et al., 2001; Demuth \& Brown, 2004; Dekovic et al., 2004; Davies \& Lindsay, 2004; Gerard et al., 2006; Housknecht \& Hango, 2006; Cui et al., 2007).

Early work in this area focused on the hypothesis that parental conflict affected children by "spilling over" into the parenting and parent-child relationship (Fauber et al., 1990; Amato, 1993; Buehler \& Gerard, 2002; Krishnakumar et al., 2003; Grych, 2005; Lindsey et al., 2006). When couples are involve in conflict, they may become more hostile, aggressive, or withdrawn from their children and more inconsistent in their control and discipline. Disruption in parenting and the quality of parent-adolescent relationship has a great influence on adolescents' wellbeing, internalizing problems and externalizing problems following divorce (Forehand et al., 1991; Buehler \& Gerard, 2002). In particular, studies have found that poor and negative parentadolescent relationship such as low level of parental warmth, involvement, support and acceptance and affection, harsh discipline and punishment are significantly related with higher level of externalizing behavior problems, delinquent and antisocial behaviors in adolescents (Amato \& Keith, 1991; Grych et al., 1992; Hetherington, 1999; Schickedanz et al., 2001; Juby \& Farrington, 2001; Huff et al., 2003; Demuth \& Brown, 2004; Dekovic et al., 2004; Gerard et al., 2006; Malete, 2007; Cui et al., 2007; Bradford et al., 2007; Breivik et al., 2009).

Amato and Keith (1991) in their meta analysis explained why some children of divorced families experience more difficulties than children from intact families. They found that children from families with high level of conflict show more behavior problems such as delinquency. Grych et al. (1992) showed that children who were exposed to frequent and intense parental hostility have higher levels of externalizing problems.

Hetherington (1999) revealed that post-divorce parental conflict was related to behavior problems among adolescents. Conflict can be repulsive if it involves physical violence or children are caught in the middle of their parents. Buehler and Gerard (2002) found that parental conflict was associated with greater use of harsh discipline, reduced levels of parental involvement, and more frequent parent and adolescent conflict, that contributes to greater levels of maladjustment in children and adolescents.

When parent-adolescent relationship is negative, adolescents are less likely to internalize parental values and norms. They may punish their parents with negative behaviors 
(Schickedanz et al., 2001). Adolescent with critical and rejecting parents may develop a negative identity; engage in behaviors that oppose to their parents' values and norms (Schickedanz et al., 2001). However in a warm and positive parent-adolescent relationship, adolescents are more interested to communicate with their parents and share with them about their daily activities. Grych and Fincham (2001) noted that important factors such as the quality of parenting and parent-children relationship may moderate the association between postdivorce parental conflict and children's adjustment.

Juby and Farrington (2001) in a study among 75 boys who were living in disrupted families examined the association between disrupted families and delinquency. The result showed that family conflict predicted high delinquency rate among boys from disrupted families. Krishnakumar et al. (2003) examined the spillover of youth perceptions of parental conflict into parenting disruption and youth behavior problems in a sample of 542 European-American and 150 African-American youth aged 10 through 18 years. Their findings indicated that parental conflict was positively related to youth problem behaviors in both European-American and African-American samples. Parental conflict was linked with youth externalizing problem behaviors through lower levels of parental monitoring, maternal acceptance, and higher levels of parent-youth conflict in European-American families.

Demuth and Brown (2004) studied the relationship between family structure, family processes, and adolescent delinquency. They believed that family structure did not have direct effect on adolescents' delinquency but it has indirect effect through family process and family relationships. They found that adolescents who live in single-parent families are significantly more delinquent than adolescents in intact families. This relationship may be due to loss of parental control, parental monitoring, and low levels of involvement and decreased in parentadolescents closeness in single-parent families.

Gerard et al. (2006) in a longitudinal research examined the association between parental conflicts, parent-child relations and youth maladjustment from middle childhood to adolescence. They reported that parental conflict is associated with adolescents' maladjustment through disruption in quality of parent-child relationship. Parental conflict resulted in punitive discipline, parental disengagement and negative parent-adolescents relationship. This study found direct association between parental conflict and externalizing problems in adolescents.

Malete (2007) in his research examined the relationship between family factors and secondary school students' externalizing behavior problems such as antisocial behavior and aggression aged12-20 years old. Results showed that high scores on antisocial behavior and aggressive symptoms were significantly related to poor parent-child relations and low parental monitoring.

Cui et al. (2007) examined reciprocal associations between marital problems and functioning and adolescent maladjustment. Their research involved 451 early adolescents and their families. Results of their research indicated that parental conflict over child rearing predicted adolescent problem behavior and maladjustment such as depressive symptoms and delinquency.

Bradford et al. (2007) conducted a study to investigate direct and indirect associations between overt and covert interparental conflict, parent-child conflict, and their links to youth problem behaviors. The sample comprised a total of 641 school age youth, ages 12 to 18 years, using a school-based survey. Analyses yielded direct positive linkages between overt and covert parental conflict and youth antisocial behavior. Significant direct associations were observed between overt conflict and antisocial behavior, with significant indirect effects through increased parent-child conflict. These findings document distinct pathways in the spillover of parental conflict to parent-child relationship and youth antisocial behavior.

Breivik et al. (2009) examined how parent-child relationship variables may function as mediators of the association between post-divorce family structures and antisocial behavior. Five parent-child relationship variables (mother/father-child conflict, parental monitoring, and mother/father-child closeness) were tested as potential mediators of the relationship between living in a single-mother or single-father families and the outcome variables in a sample of 
4,117 students aged 11 to 15 years. As hypothesized, there was a clear tendency for motherchild conflict and parental monitoring to be the most potent mediators between residing in a divorced single-mother families and adolescents' antisocial behavior. Grych (2005) reported that parents in high level of conflict serve as negative role models in which children learn to express their emotions in an inappropriate way. Consequently, it will intensify behavior problems in children of divorce.

The influence of parental conflict on adolescents' adjustment differs by gender. Some studies have shown that the association between parental conflict and child maladjustment and behavior problems is more significant for boys than girls, especially in the prediction of externalizing symptoms (Amato \& Rezak, 1994; Davies \& Lindsay, 2004). However, other findings reveal that parental conflict may actually be a stronger predictor of adjustment problems for adolescents' girl than for boys (Unger, Brown, Tressel, \& McLeod, 2000). Davies and Lindsay (2004) conducted a study on children between 10 to 15 years to investigate the relationship between parental conflict and adolescent psychological symptoms and adjustment. They found that parental conflict was a stronger predictor of adolescent internalizing problems for girls and externalizing problems for boys. Davies and Lindsay argued that girls were more communions with their parents, and they are more vulnerable to their parental conflict. In general, both boys and girls are influenced by parental post-divorce conflict in a different way. Post-divorce parental conflict tends to predict externalizing behavior problems for boys and internalizing behavior problems for girls (Grych \& Fincham, 2001).

\section{Conclusion}

The purpose of the current study is to review the relationship between post-divorce parental conflict and adolescents' delinquency of divorced families. This review concluded that parents have a powerful influence on their adolescents. Therefore, adolescent's behavioral problems could be reflected by their parents' behavior. This review highlights that post-divorce parental conflict can spill over into parental relationship and parenting behavior and consequently this leads to inappropriate nature of parent-adolescents relationship that spurs behavior problems such as high level of delinquency.

\section{References}

Amato, P. R. (1993). Children's adjustment to divorce: Theories, hypotheses, and empirical support. Journal of Marriage and Family, 55 (1), 23-38.

Amato, P. R., \& Keith, B. (1991). Parental divorce and the well-being of children: A meta analysis. Psychological Bulletin, 110(1), 26-46.

Amato, P., \& Rezac, S.J. (1994). Contact with nonresidential parents, inter-parental conflict, and children's behavior. Journal of Family Issues, 15, 191-207.

Amato, P.R. (2000). The consequences of divorce for adults and children. Journal of Marriage and the Family, 62, 1269-1287.

Amato, P.R. (2003). Reconciling divergent perspectives: Judit Wallerstein quantitative family research and children of divorce. Family Relations, 52, 332-339.

Arnett, J.J. (2004). Adolescence and emerging adulthood: A cultural approach. ( $2^{\text {nd }}$. Ed). New Jersey, Pearson Education.

Booth, A., \& Amato, P.R. (2001). Parental pre-divorce relations and offspring post divorce Well-being. Journal of Marriage and Family, 63 (1), 197-212.

Bradford, K., Burns Vaughn, L., \& Barber, B.K. (2007). When there is conflict: Inter parental conflict, parental- child conflict, and youth problem behaviors. Journal of Family Issues, 29(6), 780-805.

Breivik, K., Olweus, D., \& Endresen, I. (2009). Does the Quality of Parent-Child Relationships Mediate the Increased Risk for Antisocial Behavior and Substance Use Among Adolescents in Single-Mother and Single-Father Families? Journal of Divorce and Remarriage, 50, 400-426. 
Buehler, C., \& Gerard, J. M. (2002). Marital conflict, ineffective parenting, and children's and adolescents' maladjustment. Journal of Marriage and the Family, 64, 78-92.

Cui, M., Donnellan, M.B., \& Conger, R.D. (2007). Reciprocal influences between parents' marital problems and adolescent internalizing and externalizing behavior. Developmental Psychology, 43(6), 1544-1552.

Dare, P.S., \& Mallett, C.A. (2009). Parental Divorce: A Protection from Later Delinquency for Maltreated Children. Journal of Divorce and Remarriage, 50(6), 388-399.

Davies, P.T., \& Lindsay, L.L. (2004). Inter parental conflict and adolescent adjustment: Why does gender moderate early adolescent vulnerability. Journal of Family Psychology, 18(1), 160 170 .

Dekovic, M., Wissink, I.B., \& Meijer, A.M. (2004). The role of family and peer relations in adolescent antisocial behavior: Comparison of four ethic group. Journal of Adolescence, 27, 497-514.

Demuth, S. \& Brown, S.L. (2004). Family structure, family processes and adolescent delinquency: The significance of parental absence versus parental gender. Journal of research in crime and delinquency, 41(1), 58-81.

Dmittrieva, J., Chen, C., Greenberg, E., \& Gil-Rivas, V. (2005). Family relationship and adolescents psychosocial outcomes: Converging finding from eastern and western. Journal of Research on Adolescents, 14(4), 425-447.

Emery, R. (1999). Marriage divorce and children's adjustment. $\left(2^{\text {nd }}\right.$. ed). Beverly Hills.CA: Sage Publication.

Fauber, R., Forehand, R., Thomas, A. M., \& Wierson, M. (1990). A meditational model of the impact of marital conflict on adolescent adjustment in intact and divorced families: The role of disrupted parenting. Child Development, 61, 1112-1123.

Forehand, R., Wierson, M., Thomas, A. M., Fauber, R., Armistead, L., Kemptom, T., \& Long, N. (1991). A short-term longitudinal examination of young adolescent functioning following divorce: The role of family factors. Journal of Abnormal Child Psychology, 19, 97-111.

Gerard, J.M., Krishnakumar, A., \& Buehler, C. (2006). Marital conflict, parent-child Relations, and youth maladjustment: A longitudinal investigation of spillover effects. Journal of Family Issues, 27(7), 951-975.

Grych, J. H., \& Fincham, F. D. (2001). Inter-parental conflict and child development: theory, research, and applications. New York: Cambridge University Press.

Grych, J. H., Seid, M., \& Fincham, F. D. (1992). Assessing marital conflict from the child's perspective: The children's perception of interparental conflict scale Child Development, 63, $558-572$.

Grych, J.H. (2005). Inter-parental conflict as a risk factor for child maladjustment: Implications for the development of prevention programs. Family Court Review, 43, 97-108.

Guttman, J. \& Rosenberg, M. (2003). Emotional intimacy and children's adjustment: A comparison between single-parent, divorced and intact families. Educational Psychology, 23(4), 457-471.

Heck, C., \& Walsh, A. (2000). The effects of maltreatment and family structure on minor and serious delinquency. International Journal of Offender Therapy and Comparative Criminology, 44, 178-193.

Hetherington, E. M. (1999). Should we stay together for the sake of the children? In E. M. Hetherington (Ed.), Coping with divorce, single parenting, and remarriage: A risk and resiliency perspective. (pp. 93-116). Mahwah NJ: Erlbaum.

Hetherington, E.M. (1993). An overview of the Virginia longitudinal study of divorce and remarriage with a focus on early adolescence. Journal of Family Psychology, 7(1), 39-56. 
Hetherington, E.M. (2003). Social support and the adjustment of children in divorced and remarried families. Childhood, 10(2), 217-236.

Houseknecht, S.K., \& Hongo, D.W. (2006). The impact of marital conflict and disruption on children's health. Youth and Society, 38(1), 58-89.

Huff, C., Widner, M., \& Mccoy, K. (2003). The influence of challenging outdoor reaction parent-adolescent communication. Therapeutic Recreation Journal, 37, 18-37.

Ingram,J.R., Patchin, J.W., Huebner, B.M., McCluskey, J.D., \& Bynum, T.S. (2007). Parents, friends, and serious delinquency: An examination of direct and indirect effects among at risk early adolescents. Criminal Justice Review, 32(4), 380-400.

Juby, H., \& Farrington, D.P. (2001). Disentangling the link between disrupted families and delinquency. Brit Journal Criminal, 41, 22-40.

Kelly, J. B. (2000). Children's adjustment in conflicted marriage and divorce: A decade review of research. Journal of the American Academy of Child and Adolescent Psychiatry, 39, 963-973.

Kelly, J. B. (2003). Changing perspectives on children's adjustment following divorce: A review from the United States. Childhood, 10(2), 237-254.

Kelly, J.B. (2007). Children's living arrangements following separation and divorce: Insights from empirical research. Family Process. 46 (1), 35-52.

Kelly, J.B., \& Emery, R.E. (2003). Children's adjustment following divorce: Risk and Resilience perspectives. Family Relations, 52, 352-362.

Kim, K.L., Jackson, Y., Conrad, S.M., \& Hunter, H.L. (2008). Adolescent Report of Interparental Conflict: The Role of Threat and Self-blame Appraisal on Adaptive Outcome. Journal Child and Family Study, 17,735-751.

Krishnakumar, A., Buehler, C., \& Barber, B.K. (2003). Youth Perceptions of Interparental Conflict, Ineffective Parenting, and Youth Problem Behaviors in European-American and African-American Families. Journal of Social and Personal Relationships, 20(2), 239-260.

Lansford, J. E., Malone, P. S., Castellino, D. R., Dodge, K. A., Pettit, G. S., \& Bates, J. E. (2006). Trajectories of internalizing, externalizing, and grades for children who have and have not experienced their parents' divorce. Journal of Family Psychology, 20, 292-301.

Lindsey, E.W., Colwell, M.J., Frabutt, J.M., \& Mckinnon-Lewis, C. (2006). Family conflict in divorced and non-divorced families: Potential consequences for boys' friendship status and friendship quality. Journal of Social and Personal Relationships, 23(1), 45-63.

Malete, L. (2007). Aggressive and antisocial behaviors among secondary school student in Botsowana: The influence of family and school based factors. School Psychology International, 28(1), 90-109.

Malone, P.S., Lansford, J.E., Castellino, D.R., Berlin, L.J., Dodge, K.A., Bates, J.E., \& Pettit, G.S. (2004). Divorce and child behavior problems: Applying latent change score models to life event data. Structural Equation Modeling, 11, 401-423.

Neff, R., \& Cooper, K. (2004). Progress and parent education: Parental conflict resolution. Family Court Review, 42, 1-16.

Platt, R.A.L., Nalbone, D.P., Casanova, G.M., \& Wetchler, J.L. (2008). Parental conflict and infidelity as predictors of adult children's attachment style and infidelity. The American Journal of Family Therapy, 36, 149-161.

Price, C., \& Kunz, J. (2003). Rethinking the paradigm of juvenile delinquency as related to divorce. Journal of Divorce \& Remarriage, 39(1), 109-133.

Pruett, M.K., Williams, T.Y., Insabella, G., \& Little, T.D. (2003). Family and legal indicators of child adjustment to divorce among families with young children. Journal of Family Psychology, 17(2), 169-180. 
Sandler, I., Miles, J., Cookston, J., \& Braver, S. (2008). Effects of father and mother parenting on children's mental health in high-and low conflict divorces. Family Court Review, 46(2), 282296.

Santrock, J.W. (2007). Adolescence ( $11^{\text {th }}$.Ed.). Mc Graw Hill.

Schickedanz, J. A., Schickedanz, D.I., Forsyth, P.D., \& Forsyth, G.A. (2001). Understanding children and adolescent $\left(4^{\text {th }}\right.$.Ed.). MA: Allyn \& Bacon.

Turner, H.A., \& Kopiec, K. (2006). Exposure to inter parental conflict and psychological disorder among young adults. Journal of Family Issues, 27(2), 131-158.

Unger, D. G., Brown, M. B., Tressel, P. A., \& McLeod, L. E. (2000). Inter-parental conflict and adolescent depressed mood: The role of family functioning. Child Psychiatry and Human Development, 31, 23-41.

Vandervalk, I., Spruijt, E., Goede, M., Maas, C. \& Meeus, W. (2004) .Marital status, marital process, and parental resources in predicting adolescent emotional adjustment: A multilevel analysis. Journal of Family Issues, 25(3), 291-317. 